\title{
Immunoglobulin concentrations in human tears in ocular diseases
}

\author{
D. K. SEN AND G. S. SARIN \\ From the Department of Ophthalmology, Maulana Azad Medical College, Irwin Hospital, and \\ Guru Nanak Eye Centre, New Delhi, India
}

SUMMARY Immunoglobulin concentrations in human tears were determined in 165 patients with different eye diseases by a standard radial immunodiffusion method. IgA was present in all the samples in measurable quantity. The mean IgA values were significantly higher than the controls in patients with acute bacterial conjunctivitis, keratomalacia, corneal graft reaction, blepharoconjunctivitis, and acute keratoconjunctivitis. The values in the patients with vernal conjunctivitis, phlyctenular conjunctivitis, acute bacterial corneal ulcer, and acute endogenous uveitis were not significantly different from those in the controls. IgG could be detected in the majority of the samples but it was in measurable quantity in 18 samples. IgM could be detected in fewer samples. IgD was not detected in any of them. The study indicates that, whenever the immunoglobulin levels in tears are altered in diseased eyes, it is the IgA level that is predominantly altered and not the IgG level.

The immunoglobulin found predominantly in fluids coating mucous membrane surfaces such as the conjunctiva, respiratory tract, and gastrointestinal tract may be important local agents of a defence mechanism in initial or recurrent bacterial or other infectious processes (Little et al., 1969). Several reports (Smith et al., 1967; Douglas et al., 1967; Waldman et al., 1968) suggest that immunoglobulin A in parotid, nasal, and throat secretions plays a role in local immunity to respiratory infection. The host defence mechanism has also been detected in lacrimal and conjunctival secretions, where local humoral immunity appears to be important (Centifanto and Kaufman, 1970). An earlier study by the present authors has established the immunoglobulin levels in tears of normal Indian people (Sen et al., 1976, 1978). The purpose of the present study was to see whether there is any appreciable change in the immunoglobulin concentrations in tears in patients suffering from various ocular diseases.

\section{Patients and methods}

The study was carried out among 220 healthy people and 165 patients with different eye diseases chosen

Address for reprints: Dr D. K. Sen, Department of Ophthalmology, Maulana Azad Medical College, New Delhi-110002, India. consecutively from the Eye Outpatient Department of Irwin Hospital, New Delhi. The former group comprised people who had no evidence of ocular or systemic disease and who had attended mainly for refraction. There were 111 males and 109 females in the healthy group, and their ages ranged from 2 to 86 years. A detailed analysis of data on tear immunoglobulin levels of this healthy group has been reported earlier (Sen et al., 1978).

The patients were grouped into 3 categories according to whether they had conjunctival, corneal, or miscellaneous diseases. The number of cases in each clinical subgroup, their sex distribution, and age range are given in Table 1 . The diagnosis was established by detailed clinical examination, including slit-lamp biomicroscopy, direct and indirect ophthalmoscopy, and relevant laboratory investigations.

Tear specimens were collected by the method already described (Sen et al., 1976). They were stored at $-20^{\circ} \mathrm{C}$ until needed. IgA, IgG, IgM, and IgD were quantified by the single radial immunodiffusion technique (Mancini et al., 1965). Monospecific goat antisera against heavy chain human IgA, IgG, IgM, and IgD and the respective reference standards except that of IgA were obtained from Meloy Laboratories, Virginia, USA. The reference standard of secretory IgA, purified from human colostrum, was used. The concentrations of immunoglobulins were calculcated from the calibration curve 
Table 1 Age-sex distribution of patients and their tear $\operatorname{IgA}$ levels compared to matched controls

\begin{tabular}{|c|c|c|c|c|c|c|c|c|c|}
\hline \multirow{3}{*}{ Clinical conditions } & \multirow{3}{*}{$\begin{array}{l}\text { No. of } \\
\text { cases }\end{array}$} & \multirow{3}{*}{ Males } & \multirow{3}{*}{ Females } & \multirow{3}{*}{$\begin{array}{l}\text { Age } \\
\text { range } \\
\text { in } \\
\text { years }\end{array}$} & \multirow{3}{*}{$\begin{array}{l}\text { Size of } \\
\text { matched } \\
\text { control } \\
\text { group }\end{array}$} & \multicolumn{4}{|c|}{ IgA in $\mathrm{mg} / 100 \mathrm{ml}$} \\
\hline & & & & & & \multicolumn{2}{|c|}{ Clinical conditions } & \multicolumn{2}{|c|}{ Matched control } \\
\hline & & & & & & $M e a n \pm S D$ & $\begin{array}{l}C V \\
(\%)\end{array}$ & Mean $\pm S D$ & $\begin{array}{l}C V \\
(\%)\end{array}$ \\
\hline \multicolumn{10}{|l|}{ Group $A$} \\
\hline Acute bacterial conjunctivitis & 40 & 23 & 17 & $5-55$ & 90 & $33 \cdot 9 \pm 18 \cdot 8$ & $55 \cdot 4$ & $26 \cdot 0 \pm 13 \cdot 2$ & $50 \cdot 7$ \\
\hline Phlyctenular conjunctivitis & 22 & 13 & 9 & $7-20$ & 60 & $23 \cdot 0 \pm 14 \cdot 0$ & $60 \cdot 8$ & $25 \cdot 8 \pm 12 \cdot 9$ & $50 \cdot 0$ \\
\hline Vernal conjunctivitis & 10 & 4 & 6 & $7-40$ & 40 & $33 \cdot 5 \pm 20 \cdot 9$ & $62 \cdot 3$ & $26 \cdot 5 \pm 15 \cdot 1$ & $56 \cdot 9$ \\
\hline \multicolumn{10}{|l|}{ Group B } \\
\hline Keratomalacia & 14 & 6 & 8 & $4-12$ & 30 & $54 \cdot 2 \pm 29 \cdot 5$ & $54 \cdot 4$ & $26 \cdot 3 \pm 13 \cdot 6$ & $51 \cdot 7$ \\
\hline Corneal graft reaction & 6 & 6 & 0 & $26-52$ & 36 & $41 \cdot 8 \pm 17 \cdot 5$ & $41 \cdot 8$ & $28 \cdot 0 \pm 16 \cdot 4$ & $58 \cdot 5$ \\
\hline Acute bacterial corneal ulcer & 15 & 6 & 9 & $6-75$ & 42 & $20 \cdot 4 \pm 19 \cdot 6$ & $96 \cdot 0$ & $28 \cdot 8 \pm 20 \cdot 2$ & $70 \cdot 1$ \\
\hline \multicolumn{10}{|l|}{ Group C } \\
\hline Blepharoconjunctivitis & 11 & 6 & 5 & $10-45$ & 45 & $68 \cdot 2 \pm 34 \cdot 2$ & $50 \cdot 1$ & $30 \cdot 0 \pm 15 \cdot 9$ & $53 \cdot 0$ \\
\hline Acute keratoconjunctivitis & 16 & 4 & 12 & $11-54$ & 45 & $47 \cdot 7 \pm 28 \cdot 5$ & $59 \cdot 7$ & $27 \cdot 4 \pm 15 \cdot 2$ & $55 \cdot 4$ \\
\hline Acute endogenous uveitis & 31 & 22 & 9 & $14-65$ & 31 & $28 \cdot 5 \pm 15 \cdot 1$ & $52 \cdot 9$ & $31 \cdot 4 \pm 17 \cdot 3$ & $55 \cdot 0$ \\
\hline
\end{tabular}

constructed by incorporating 3 known concentrations of standard for every set of immunoglobulin determinations. The lower level of sensitivity of the plates was $1 \mathrm{mg} / 100 \mathrm{ml}$.

It had been found in our earlier study among normal people that the IgA level varied according to age and sex (Sen et al., 1978). Thus a direct comparison would have been invalid, since the various clinical subgroups differed considerably from the healthy group in their age-sex distribution. Therefore, to ensure the validity of the conclusions, random samples were drawn from the healthy group to match the clinical subgroup in respect of its size and age-sex composition for comparing the IgA values.

\section{Results}

IgA was present in all the tear samples in measurable quantity. The mean, standard deviation, and coefficient of variation $(\mathrm{CV})$ of $\operatorname{IgA}$ values obtained in different clinical subgroups and the respective matched control groups are given in Table 1 .

In group $A$ only patients in the subgroup acute bacterial conjunctivitis were found to have a significantly higher mean IgA level than the matched controls $(t=2.52$ for $128 \mathrm{df}, \mathrm{P}<0.02)$. The values in the case of phlyctenular conjunctivitis were not significantly different from the matched controls $(t=0.85$ for $80 \mathrm{df}, \mathrm{P}>0.3)$. The apparently high mean value in cases of vernal conjunctivitis did not attain statistical significance $(t=1.21$ for $48 \mathrm{df}$,
$P>0 \cdot 2$ ). In group $B$ patients with keratomalacia $(t=4.04$ for $42 \mathrm{df}, \mathrm{P}<0.001)$ and corneal graft reaction $(t=2.04$ for $40 \mathrm{df}, \mathrm{P}<0.05)$ were found to have mean IgA levels significantly higher than the matched controls. Patients with acute bacterial corneal ulcer had a lower value than matched controls, but the difference did not attain statistical significance $(t=1.53$ for $55 \mathrm{df}, 0 \cdot 1<\mathrm{P}<0.2)$. In group $C$ patients with blepharoconjunctivitis and acute keratoconjunctivitis were found to have a significantly higher mean IgA levels $(t=4.46$ for $54 \mathrm{df}, \mathrm{P}<0.001$, and $t=2.58$ for $59 \mathrm{df}, \mathrm{P}<0.01$ ) than the respective matched controls, whereas those with acute endogenous uveitis were not significantly different from the matched control $(t=0.70$ for $60 \mathrm{df}, \mathrm{P}>0.40$ ).

IgG could be detected in 137 samples, but it was measurable in only 18 samples (Table 2). IgM could be detected in 23 samples but could be measured in 7 (Table 3). IgD was not detected in any of them. In the healthy group of 220 people IgG was detected in 200 and IgM in only 7 samples. In all those samples positive for IgG and IgM the immunoglobulin was present only in trace amounts $(<1 \mathrm{mg} / 100 \mathrm{ml})$. IgD was not detected in any sample.

\section{Discussion}

Several studies have been reported on immunoglobulin levels in tears of normal persons (Chodirker and Tomasi, 1963; Barnett, 1968; Josephson and Weiner, 1968; Little et al., 1969; Knopf et al., 1970; 
Immunoglobulin concentrations in human tears in ocular diseases

Table 2 Tear IgG in $\mathrm{mg} / 100 \mathrm{ml}$ in various eye diseases

\begin{tabular}{|c|c|c|c|c|c|}
\hline \multirow[t]{2}{*}{ Clinical conditions } & \multirow[t]{2}{*}{ No. of cases } & \multirow{2}{*}{$\begin{array}{l}\text { No. of cases } \\
\text { where not } \\
\text { detectable }\end{array}$} & \multirow{2}{*}{$\begin{array}{l}\text { No. of cases } \\
\text { with trace } \\
\text { amounts }\end{array}$} & \multicolumn{2}{|c|}{$\begin{array}{l}\text { Present in measurable } \\
\text { quantity }\end{array}$} \\
\hline & & & & No. of cases & Range \\
\hline \multicolumn{6}{|l|}{ Group $A$} \\
\hline Acute bacterial conjunctivitis & 40 & 7 & 28 & 5 & $3 \cdot 5-11 \cdot 5$ \\
\hline Phlyctenular conjunctivitis & 22 & 2 & 19 & 1 & 1.9 \\
\hline Vernal conjunctivitis & 10 & 2 & 7 & 1 & $5 \cdot 9$ \\
\hline \multicolumn{6}{|l|}{ Group B } \\
\hline Keratomalacia & 14 & 3 & 11 & 0 & 一 \\
\hline Corneal graft reaction & 6 & 0 & 4 & 2 & 3.3 and 6.2 \\
\hline Acute bacterial corneal ulcer & 15 & 3 & 10 & 2 & 2.9 and 3.5 \\
\hline \multicolumn{6}{|l|}{ Group C } \\
\hline Blepharoconjunctivitis & 11 & 4 & 5 & 2 & $4 \cdot 5$ and $19 \cdot 6$ \\
\hline Acute keratoconjunctivitis & 16 & 4 & 9 & 3 & $11 \cdot 8-16 \cdot 0$ \\
\hline Acute endogenous uveitis & 31 & 3 & 26 & 2 & 3.9 and 8.0 \\
\hline
\end{tabular}

Table 3 Tear IgM in $\mathrm{mg} / 100 \mathrm{ml}$ in various eye diseases

\begin{tabular}{|c|c|c|c|c|c|}
\hline \multirow[t]{2}{*}{ Clinical conditions } & \multirow[t]{2}{*}{ No. of cases } & \multirow{2}{*}{$\begin{array}{l}\text { No. of cases } \\
\text { where not } \\
\text { detectable }\end{array}$} & \multirow{2}{*}{$\begin{array}{l}\text { No. of cases } \\
\text { with trace } \\
\text { amounts }\end{array}$} & \multicolumn{2}{|c|}{$\begin{array}{l}\text { Present in measurable } \\
\text { quantity }\end{array}$} \\
\hline & & & & No. of cases & Range \\
\hline \multicolumn{6}{|l|}{ Group $A$} \\
\hline Acute bacterial conjunctivitis & 40 & 32 & 5 & 3 & $6 \cdot 5-9 \cdot 5$ \\
\hline Phlyctenular conjunctivitis & 22 & 19 & 2 & 1 & $7 \cdot 3$ \\
\hline Vernal conjunctivitis & 10 & 10 & 0 & 0 & - \\
\hline \multicolumn{6}{|l|}{ Group B } \\
\hline Keratomalacia & 14 & 11 & 1 & 2 & 3.7 and 5.8 \\
\hline Corneal graft reaction & 6 & 5 & 1 & 0 & - \\
\hline Acute bacterial corneal ulcer & 15 & 13 & 2 & 0 & - \\
\hline \multicolumn{6}{|l|}{ Group C } \\
\hline Blepharoconjunctivitis & 11 & 10 & 1 & 0 & - \\
\hline Acute keratoconjunctivitis & 16 & 14 & 2 & 0 & - \\
\hline Acute endogenous uveitis & 31 & 28 & 2 & 1 & $4 \cdot 3$ \\
\hline
\end{tabular}

Brauninger and Centifanto, 1971; Sen et al., 1976), but there is little information on the level of immunoglobulin concentrations in tears in diseased eyes. In the few published reports the numbers of cases studied were small. Bluestone et al. (1975) studied a few cases with miscellaneous eye diseases and found only the IgA level rising in the tears. Chandler et al. (1974), on the other hand, found the IgA level remaining remarkably constant despite the presence of disease and the IgG level rising in such conditions. McClellan et al. (1973) also found the IgG level rising in diseases of the external eye and thought the rise was probably due to transudation of serum proteins into the tears. However, the present study indicates that whenever there is alteration in the level of immunoglobulins in tears in the diseased eyes it is the level of $\operatorname{IgA}$ that is predominantly altered. 
The level of $\operatorname{IgA}$ was significantly raised in acute bacterial conjunctivitis, blepharoconjunctivitis, acute keratoconjunctivitis, keratomalacia, and corneal graft reaction. In cases of protein-calorie malnutrition serum immunogloblulins and those in external secretions are expected to be low. However, an increase of tear IgA level in keratomalacia can be explained on the basis of repeated infection that occurs at the site in such cases. Mata and Faulk (1973) reported an increase of serum IgA values in protein-calorie malnutrition, and this has been attributed to repeated antigenic stimulation via the respiratory and gastrointestinal tracts (Sirisinha et al., 1975). It is interesting to note that cases of acute bacterial corneal ulcer had a lower IgA level than the controls. However, further study would be needed to determine whether or not a state of local deficiency of IgA exists in such cases. It is of interest that secretory $\operatorname{IgA}$ in tears is remarkably low in patients with ocular complications following treatment with beta-blockers (Garner and Rahi, 1976).

In phlyctenular conjunctivitis and acute endogenous uveitis the stimulation is systemic and therefore no rise in the IgA level in tears was expected. However, there was also no appreciable change in the values of the immunoglobulins in vernal conjunctivitis, in which the stimulation is at the local site.

In most of the cases with a higher level of IgA in tears there was no corresponding rise in the level of IgG. This suggests increased local production of IgA as a result of stimulation at the site, for leakage of serum into the tears would have substantially raised the level of IgG. Our findings of generally low IgG level in the tear samples from diseased eyes are in agreement with Bluestone et al. (1975), who found IgG usually detectable but occasionally quantifiable even in tears from diseased eyes.

Thanks are due to Dr R. Thompson, of Birmingham, for donated purified colostrum standard. The valuable help of Dr Kumal Saha, of Govind Ballabh Pant Hospital, New Delhi, is acknowledged. Thanks are also due to Mr G. P. Mathur, Tuberculosis Centre, New Delhi, for the statistical analysis of our data.

\section{References}

Barnett, E. V. (1968). Quantitation of immunoglobulins and L-chains by complement fixation tests. Journal of Immunology, 100, 1093-1100.

Bluestone, R., Easty, D. L., Goldberg, L. S., Jones, B. R., and Petit, T. H. (1975). Lacrimal immunoglobulins and complement quantified by counter-immunoelectrophoresis. British Journal of Ophthalmology, 59, 279-281.

Brauninger, G. E., and Centifanto, Y. M. (1971). Immunoglobulin $\mathrm{E}$ in human tears. American Journal of Ophthalmology, 72, 558-561.

Centifanto, Y. M., and Kaufman, H. E. (1970). Infection and Immunity, 2, 778. Cited by Bluestone et al. (1975). British Journal of Ophthalmology, 59, 279-281.

Chandler, J. W., Leder, R., Kaufman, H. E., and Caldwell, J. R. (1974). Quantitative determination of complement component and immunoglobulins in tears and aqueous humour. Investigative Ophthalmology, 13, 151-153.

Chodirker, W. B., and Tomasi, T. B. Jr. (1963). Immunoglobulins: quantitative relationships in human serum and non-vascular fluids. Science, 142, 1080-1081.

Douglas, R. G., Rossen, R. D., Butler, W. T., and Couch, R. B. (1967). Rhinovirus neutralizing antibody in tears, parotid saliva, nasal secretions and serum. Journal of Immunology, 99, 297-303.

Garner, A., and Rahi, A. H. S. (1976). Practolol and ocular toxicity: antibiotics in serum and tears. British Journal of Ophthalmology, 60, 684-686.

Josephson, A. S., and Weiner, R. S. (1968). Studies of the proteins of lacrimal secretions. Journal of Immunology, 100, 1080-1092.

Knopf, H. L. S., Bertran, D. M., and Kapikian, A. Z. (1970). Demonstration and characterization of antibody in tears following intranasal vaccination with inactivated type 13 rhinovirus. A preliminary report. Investigative Ophthalmology, 9, 727-734.

Little, J. M., Centifanto, Y. M., and Kaufman, H. E. (1969). Immunoglobulins in human tears. American Journal of Ophthalmology, 68, 898-905.

Mancini, G., Carbonara, A. O., and Heremans, J. F. (1965). Immunochemical quantitation of antigens by radial immunodiffusion. International Journal of Immunochemistry, 2, 235-254.

Mata, L., and Faulk, W. P. (1973). The immune response of malnourished subjects with special reference to measles. Archivos Latinoamericanos de Nutricion, 23, 345-362.

McClellan, B. H., Whitney, C. R., Newman, L. P., and Allansmith, M. R. (1973). Immunoglobulins in tears. American Journal of Ophthalmology, 76, 89-101.

Sen, D. K., Sarin, G. S., Mani, K., and Saha, K. (1976). Immunoglobulins in tears of normal Indian people. British Journal of Ophthalmology, 60, 302-304.

Sen, D. K., Sarin, G. S., Mathur, G. P., and Saha, K. (1978). Biological variation of immunoglobulin concentrations in normal human tears related to age and sex. Acta Ophthalmologica, 56, 439-444.

Sirisinha, S., Suskind, R., Edelman, R., Asvaperka, C., and Olsen, R. E. (1975). Secretory serum IgA in children with protein calorie malnutrition. Pediatrics, 55, 166-169.

Smith, C. B., Bellanti, J. A., and Chanock, R. M. (1967). Immunoglobulins in serum and nasal secretions following infection with type 1 parainfluenza virus and injection of inactivated vaccines. Journal of Immunology, 99, 133-141.

Waldman, R. H., Maun, J. J., and Kasel, J. A. (1968). Influenza virus neutralizing antibody in human respiratory secretions. Journal of Immunology, 100, 80-85. 